\title{
Article \\ Effects of Early, Small-Scale Nitrogen Addition on Germination and Early Growth of Scots Pine (Pinus sylvestris) Seedlings and on the Recruitment of the Root-Associated Fungal Community
}

\author{
David Castro $^{1,+} \mathbb{D}$, Andreas N. Schneider ${ }^{2,+} \mathbb{D}$, Mattias Holmlund ${ }^{3}$, Torgny Näsholm ${ }^{3}$, Nathaniel R. Street ${ }^{2} \mathbb{D}$ \\ and Vaughan Hurry ${ }^{1, *(D)}$ \\ 1 Umeå Plant Science Centre, Department of Forest Genetics and Plant Physiology, Swedish University of \\ Agricultural Sciences, 90183 Umeå, Sweden; david.castro@slu.se \\ 2 Umeå Plant Science Centre, Department of Plant Physiology, Umeå University, 90187 Umeå, Sweden; \\ andreas.schneider@umu.se (A.N.S.); nathaniel.street@umu.se (N.R.S.) \\ 3 Department of Forest Ecology and Management, Swedish University of Agricultural Sciences, \\ 90183 Umeå, Sweden; mattias.holmlund@slu.se (M.H.); torgny.nasholm@slu.se (T.N.) \\ * Correspondence: vaughan.hurry@slu.se \\ + These authors contributed equally to this work.
}

check for

updates

Citation: Castro, D.; Schneider, A.N.; Holmlund, M.; Näsholm, T.; Street,

N.R.; Hurry, V. Effects of Early,

Small-Scale Nitrogen Addition on

Germination and Early Growth of

Scots Pine (Pinus sylvestris) Seedlings and on the Recruitment of the

Root-Associated Fungal Community.

Forests 2021, 12, 1589. https://

doi.org/10.3390/f12111589

Academic Editor: Leena Hamberg

Received: 27 September 2021

Accepted: 16 November 2021

Published: 18 November 2021

Publisher's Note: MDPI stays neutral with regard to jurisdictional claims in published maps and institutional affiliations.

Copyright: (c) 2021 by the authors. Licensee MDPI, Basel, Switzerland. This article is an open access article distributed under the terms and conditions of the Creative Commons Attribution (CC BY) license (https:/ / creativecommons.org/licenses/by/ $4.0 /)$.

\begin{abstract}
Scots pine (Pinus sylvestris L.) is one of the most economically important species to the Swedish forest industry, and cost-efficient planting methods are needed to ensure successful reestablishment after harvesting forest stands. While the majority of clear-cuts are replanted with pre-grown seedlings, direct seeding can be a viable option on poorer sites. Organic fertilizer has been shown to improve planted seedling establishment, but the effect on direct seeding is less well known. Therefore, at a scarified (disc trencher harrowed) clear-cut site in northern Sweden, we evaluated the effect of early, small-scale nitrogen addition on establishment and early recruitment of fungi from the disturbed soil community by site-planted Scots pine seeds. Individual seeds were planted using a moisture retaining germination matrix containing $10 \mathrm{mg}$ nitrogen in the form of either arginine phosphate or ammonium nitrate. After one growing season, we collected seedlings and assessed the fungal community of seedling roots and the surrounding soil. Our results demonstrate that early, small-scale $\mathrm{N}$ addition increases seedling survival and needle carbon content, that there is rapid recruitment of ectomycorrhizal fungi to the roots and rhizosphere of the young seedlings and that this rapid recruitment was modified but not prevented by $\mathrm{N}$ addition.
\end{abstract}

Keywords: boreal forest; clear-cut; fungal community composition; ectomycorrhiza; Scots pine; nitrogen addition; mycobiome

\section{Introduction}

Swedish forested land makes up part of the wider boreal forest area, which is the largest terrestrial biome covering more than $10 \%$ of the land surface, extending across Eurasia and North America between $45^{\circ}$ to $70^{\circ}$ northern latitude [1-3]. It is characterized by nitrogen $(\mathrm{N})$ limitation, slow regeneration, low plant community species richness and one of the largest carbon (C) pools in the world [1,3-5]. Plants growing in the boreal forest form symbioses with ectomycorrhizal fungi (ECM), one of the most diverse groups of soil organisms that establish mutualistic interactions with plants [6,7]. ECM are generally considered to enhance nutrient and water uptake by plants, seedling establishment and survival, and increased plant resilience against environmental stressors [8]. However, the ecological role of ECM can vary from mutualistic to parasitic [9-11], and in situations such as strong $\mathrm{N}$ limitation, mycorrhizal fungi can immobilize available $\mathrm{N}$ and aggravate plant $\mathrm{N}$ limitation [12-14].

In Sweden, forested land accounts for approximately $60 \%$ of the country [15], and forestry is one of the most important export industries [2], with the conifers Norway spruce 
(Picea abies (L.) H. Karst.) and Scots pine (Pinus sylvestris L.) being the ecologically dominant and economically most important species $[16,17]$. The current Swedish silvicultural strategy, which has been used since the mid 20th century, focuses on clear-cutting mature Norway spruce and Scots pine forests that are re-planted within a few years of harvesting [18,19]. Using this method, approximately 50,000 to 70,000 individual clear-cuts, covering between 150,000-300,000 ha, are created each year [18]. The majority of clear-cuts are replanted with pre-grown seedlings, but direct seeding can be a viable alternative for low-nutrient sites with adequate moisture, limited competing vegetation, and where Hylobius abietis attacks are minimal $[20,21]$. Prior to any type of re-planting, site soils are scarified to improve soil properties (e.g., soil temperature and porosity) [22]. In addition, soil scarification increases natural regeneration [23] and seedling survival [24] by reducing above- and belowground competition with older trees $[25,26]$. Despite the benefits of soil scarification, it also increases nutrient leaching and site water loss $[24,27,28]$. Moreover, clear-cutting these $\mathrm{N}$-limited boreal forests leaves the root-associated ECM fungi without photosynthetically fixed $C$, leading to a rapid decrease in biomass within the soil community $[29,30]$. In addition, scarification disturbs the upper, organic layer of the soil to expose the deeper mineral horizon [31,32], further disrupting the mycorrhizal network and increasing fungal necromass $[30,33]$. Scarification also exposes dead fine roots and complex C, increasing available carbon sources for opportunistic saprotrophs, which have been shown to increase in abundance in soil communities after both clear-cutting and forest fires [34-37]. Climate change will continue to drive increases in air and soil temperatures and the frequency and severity of drought in boreal forests [38]. These ongoing changes to the boreal environment also have the potential to alter plant-ECM interactions, with higher soil temperatures known to reduce ECM formation $[39,40]$ at a time when the establishment of ECM symbiosis has the potential to enhance seedling drought tolerance [41,42].

In order to alleviate $\mathrm{N}$ limitation in the Swedish boreal forest soils, fertilization with inorganic $\mathrm{N}$ has been one of the most used strategies to improve tree growth and forest yield when used in the final 10 years prior to harvest [43-45]. Inorganic $\mathrm{N}$ addition has also been used extensively to produce high-quality seedlings in nurseries, but this often results in a reduction of the seedling root to shoot ratio $[46,47]$. Recently, it has been found that the production of seedlings using an organic $\mathrm{N}$ fertilizer produces high-quality seedlings with a well-developed root system, which improves out-planting performance [46,48]. However, it is less well known whether direct, small-scale $\mathrm{N}$ addition to site-planted seeds can improve early establishment and survival, and how this impacts early ECM fungal recruitment. Here, we used orchard-produced seeds supplied with controlled addition of inorganic and organic $\mathrm{N}$ sources supplied in a moisture-retaining and biodegradable germination matrix (seedPAD ${ }^{\mathrm{TM}}$; Figure S1), to investigate the role of early, small-scale $\mathrm{N}$ addition on seed germination and seedling establishment and fungal recruitment in situ on a scarified clear-felling site.

\section{Materials and Methods}

\subsection{Site Description}

The field site is located at $63^{\circ} 28^{\prime} \mathrm{N}, 17^{\circ} 29^{\prime} \mathrm{E}$ in the Svanatjärn area in northern Sweden (Figure S2A) and was part of a production forest belonging to Holmen Skog AB that was harvested in 2014, followed by scarification during the autumn of 2016. Prior to harvest, the forest was a mix of Scots pine and Norway spruce, and the trees were between 90 to 110 years old, growing on a podzol soil. The topography of the site is relatively flat with a slight slope toward the Svanatiärn lake shore, where water saturates the soil. Monthly mean temperatures at the site during the growing season range from $14{ }^{\circ} \mathrm{C}$ in July to $4{ }^{\circ} \mathrm{C}$ in October. In 2017, the mean temperature in summer was approximately $0.5^{\circ} \mathrm{C}$ higher than normal, while in autumn it was approximately $0.7^{\circ} \mathrm{C}$ lower. Precipitation at the site ranges from $56 \mathrm{~mm}$ per month in June, increasing to $78 \mathrm{~mm}$ in July and decreasing to $45 \mathrm{~mm}$ in October (Figure S3). The observed precipitation in 2017 was 30\% lower in June, 
approximately 20\% higher during July and August, and around 50\% lower in September (Figure S3).

\subsection{Planting, Treatment and Sampling}

In September 2014, an area of approximately 2.4 ha was harvested and subsequently scarified using a disc trencher to prepare for manual planting. From the site, a smaller area of about 0.9 ha was selected and on 15 June 2017, 300 seedPADs (seedPAD ${ }^{\mathrm{TM}}$, Arevo AB, Umeå, Sweden), each containing one Scots pine (Pinus sylvestris) seed, were placed on top of the exposed mineral soil. These seedPADs represented three different treatments, with 100 seedPADs containing $10 \mathrm{mg}$ nitrogen $(\mathrm{N})$ in the form of arginine phosphate, 100 seedPADs containing $10 \mathrm{mg} \mathrm{N}$ in the form of ammonium nitrate, and 100 controls containing no added N (Figure S1). They were distributed across three different sub-plots within the selected planting area (Figure S2B). At the end of the first growing season, on 20 October 2017 , all surviving seedlings were collected without damaging the root system. The roots were washed with distilled water and separated from the shoot, and both root and shoot were weighed. These were then stored separately at $-80^{\circ} \mathrm{C}$ until further processing. The soil surrounding the root system (from now on referred to as the 'ectorhizosphere') was also collected and stored separately at $-80^{\circ} \mathrm{C}$. In parallel, soil samples from the scarified site were collected to assess the effect of clear-cutting and scarification on the fungal community (hereafter 'scarified soil'). Soil was sampled from the upper $10 \mathrm{~cm}$ of the soil profile, and three cores in a triangle of around $15 \mathrm{~cm}$ side length were pooled for one sample.

\subsection{Carbon and Nitrogen Content}

Needle samples were ground to a fine powder in liquid nitrogen and air-dried at $70{ }^{\circ} \mathrm{C}$ until constant weight. Soil samples were air-dried at $70{ }^{\circ} \mathrm{C}$ until constant weight and sieved $(<2 \mathrm{~mm})$. The $\mathrm{C}$ and $\mathrm{N}$ content of $5 \mathrm{mg}$ of the dried needle and soil samples were determined by conversion to $\mathrm{CO}_{2}$ and $\mathrm{N}_{2}$ by combustion and measured with an isotope ratio mass spectrometer (DeltaV, Thermo Fisher Scientific, Bremen, Germany), following the method of Werner et al. [49].

\subsection{Genomic DNA Extraction}

Genomic DNA from the rinsed roots was extracted using a cetyl trimethylammonium bromide (CTAB) based method [50]. Briefly, mortar-ground samples were homogenized and washed for cleaning with chloroform:isoamyl alcohol (24:1). After cleaning, the genomic DNA was precipitated with cold isopropanol and cleaned further with $80 \%$ ethanol before being resuspended in $10 \mathrm{mM}$ TRIS buffer ( $\mathrm{pH}$ 8.5). Co-extracted RNA was eliminated with RNase A (10 mg/mL). The ectorhizosphere and scarified soil samples were freezedried prior to DNA extraction. Soil DNA was extracted using the DNeasy PowerLyzer PowerSoil Kit (QIAGEN, Hulsterweg, The Netherlands) following the manufacturer's instructions. Purity was assessed using a NanoDrop 2000 Spectrophotometer (ThermoFisher Scientific, Waltham, MA, USA) and the concentration was quantified using a QuBit 2.0 fluorometer (ThermoFisher Scientific). Before PCR amplification, DNA was diluted to a concentration of $5 \mathrm{ng} / \mu \mathrm{L}$.

\subsection{PCR Amplicon and Sequencing}

The amplification protocol was based on the procedure proposed by Beckers et al. [51]. Briefly, PCR amplification was performed in a two-step PCR; in the first step, the primers gITS7 and ITS4 (Table S1) targeting for the internal transcribed spacer (ITS) region were used to amplify the fungal ITS2 region $[52,53]$. The PCR reactions were performed using HotStar HiFidelity Kit (QIAGEN, The Netherlands) according to the manufacturer's instructions, and $0.5 \mathrm{ng} / \mu \mathrm{L}$ of bovine serum albumin (BSA) (Sigma-Aldrich, St. Louis, MO, USA) in a final volume of $25 \mu \mathrm{L}$. The PCR amplification was run in triplicate for each sample. Five min at $95^{\circ} \mathrm{C}$ were used for initial activation of the polymerase, then $15 \mathrm{~s}$ at $94{ }^{\circ} \mathrm{C}$ for denaturation, $1 \mathrm{~min}$ at $55^{\circ} \mathrm{C}$ for annealing, and $45 \mathrm{~s}$ at $72{ }^{\circ} \mathrm{C}$ for extension, repeated 35 times; 
for final extension, $10 \mathrm{~min}$ at $72{ }^{\circ} \mathrm{C}$ were used. Triplicate PCR products were then pooled, and PCR amplification success was confirmed using a $1.2 \%$ agarose gel. Twenty microliters of each sample was used for clean-up using AMPure XP magnetic beads (Beckman Coulter Genomics, Danvers, MA, USA) following the manufacturer's instructions, and $2.5 \mu \mathrm{L}$ of the clean product was used for the second PCR step, where each sample was assigned a unique pair of barcodes (Table S2). The PCR amplification program used was the same as before, except 20 cycles were used instead of 35 . Five microliters of each sample was pooled into one library, and the resulting pool was cleaned with AMPure XP magnetic beads. Library concentration was assessed with Qubit 2.0 and further purified to the desired fragment length (350-800 bp, accounting for variability of the ITS region) using BluePippin (Sage Science, Beverly, MA, USA) following the manufacturer's instructions. Final concentration was measured with QuBit 2.0, and the library was diluted to $10 \mathrm{nM}$. A fungal mock community, described in Haas et al. [54], was used as a positive control, and water samples as negative controls; both mock and water were treated as samples through the amplification and sequencing process.

The library pools were sequenced at the Science for Life laboratory in Stockholm, using an Illumina MiSeq and 600 cycles, yielding paired end reads of 300 bp length. Raw data were demultiplexed and quality filtered at the sequencing facility prior to delivery.

\subsection{Sequence Analysis}

The Illumina data were processed using QIIME2 [55] version 2019.1. Raw sequence data were imported using the q2-import plugin using the setting for Illumina fastq files, followed by denoising with Dada2 [56] via q2-dada2 denoise-paired, setting truncation at $301 \mathrm{bp}$ for forward read and 300 for reverse. Taxonomy was assigned with q2-feature classifier [57] plugin using the UNITE database [58] (version 8.0) at a $97 \%$ similarity and dynamic level. Amplicon sequence variants (ASVs) were aligned with MAFFT [59] and used to infer a phylogenetic tree using FastTree [60], both processes via q2-phylogeny pipeline align-to-tree-mafft-fasttree using default settings.

To assign fungal functional guilds, we used the FUNGuild [61] Python script Guilds_v1.1.py (available at https:/ / github.com/UMNFuN/FUNGuild, accessed on 17 November 2021) using the author's default settings. Taxa not classified by FUNGuild were completed manually through literature searches, wherever possible.

\subsection{Statistics}

The "kruskal" function of the agricolae package [62] was used to assess the effect of arginine phosphate or ammonium nitrate fertilization on $\mathrm{C}$ and $\mathrm{N}$ content of the soil, ectorhizosphere and needles ( $\mathrm{C}$ or $\mathrm{N}$ content $\sim$ Fertilization type) and seedling growth (root/shoot mass $\sim$ Fertilization type). The function provides Fisher's least significant difference (LSD) as post hoc analysis and statistical grouping based on Bonferroni correction when significant differences are detected in the Kruskal-Wallis test $(\alpha=0.05)$. Statistical differences in the survival rate were tested using a Cox proportional hazards regression model using the "coxph" function from the survival package $[63,64]$ to assess the hazard ratio of the arginine phosphate- or ammonium nitrate-treated seedlings compared to the control.

Sequence analysis outputs were performed in R (Version 3.5.3) [65] and analyzed with the phyloseq package [66]. Prior to any analysis, ASVs with lower than 10 sequences were removed from the dataset using the "filterfun" function from the genefilter package [67]. Additionally, ASVs with an abundance lower than $0.005 \%$ per sample type were also removed. By doing this, 1214 low abundant ASVs were removed from the dataset. Finally, one sample with a library size lower than 10,000 filtered reads was removed from the dataset.

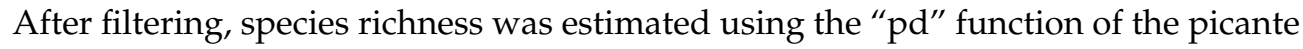
package [68] after rarefaction of the samples to 10,894 reads, which was the minimum number of reads of a sample in the dataset. The Shannon diversity index was estimated 
from raw, non-rarefied samples using the "diversity" function from the vegan package [69]. The "kruskal" function [62] was used to perform the Kruskal-Wallis rank sum test to assess the effect of arginine phosphate or ammonium nitrate fertilization on the fungal diversity (Shannon Index $\sim$ Fertilization type). At the same time, the effect of the different sample types on the fungal diversity was tested (Shannon Index $\sim$ Sample type).

Beta diversity was tested using the "ordinate" function from the phyloseq package, using Bray-Curtis to build the distance matrix with the rarefied samples and principal coordinate analysis (PCoA) for visualization. Changes in the community composition were tested using PERMANOVA with the vegan package [69], testing the effect of sample type and fertilization. Kruskal-Wallis was used to test any further differences between the different levels. Statistical groups were assigned based on Fisher's least significant difference (LSD) test.

To test for significant differences in abundance of the ASVs, we used the DESeq function of DESeq2 package [70] to estimate a sequencing library size factor and variance dispersion prior to fitting a generalized linear model (GLM) using the non-normalized data. Results of pairwise comparison of sample types with Log2fold change $>0.5$ and adjusted $p$-value $<0.01$ were used for visualization.

\section{Results}

\subsection{Site Description}

To characterize the mineral soil exposed by scarification, soil carbon $(C)$ and nitrogen (N) content were measured at three locations within the experimental site covering the areas where the different seedPAD treatments were placed. The $\mathrm{C}$ and $\mathrm{N}$ content were highly variable in the scarified soil samples, indicative of mixing of the organic and mineral soils during scarification (Figure 1D,E). To assess whether $\mathrm{N}$ supplementation from the seedPADs altered soil $\mathrm{N}$ or $\mathrm{C}$, the soil surrounding the seedling root systems (i.e., ectorhizosphere) was measured. The ectorhizosphere soil was less variable than the more mixed scarified soil but was not statistically different from it (Figure 1A-C; KruskalWallis $p$-value $>0.05$ ). Furthermore, there were no significant differences between the ectorhizosphere soil from the different treatment subsites (Figure 1D-F; Kruskal-Wallis p-value $>0.05)$. Thus, the soil across the different subsites was generally similar in $\mathrm{N}$ and $\mathrm{C}$ content and there was no evidence of significant $\mathrm{N}$ enrichment from the SeedPADs to the ectorhizosphere 4 months after planting.

\subsection{Nitrogen Addition Increases Seedling Survival but Not Early Biomass}

Seed germination and seedling survival increased 1.5 -fold relative to the control when seeds were supplemented with either arginine phosphate or ammonium nitrate (Cox proportional hazard $p$-value $<0.05$; Figure 2A). Furthermore, supplementation with either arginine phosphate or ammonium nitrate increased total needle $C$ content (Kruskal-Wallis p-value > 0.05; Figure 2B). Although the higher survival and increase in needle C of Nenriched seedlings was not reflected in statistically greater overall shoot or root biomass, supplementation with arginine phosphate and ammonium nitrate did tend to increase shoot biomass compared to the control (Figure 2E,F). 

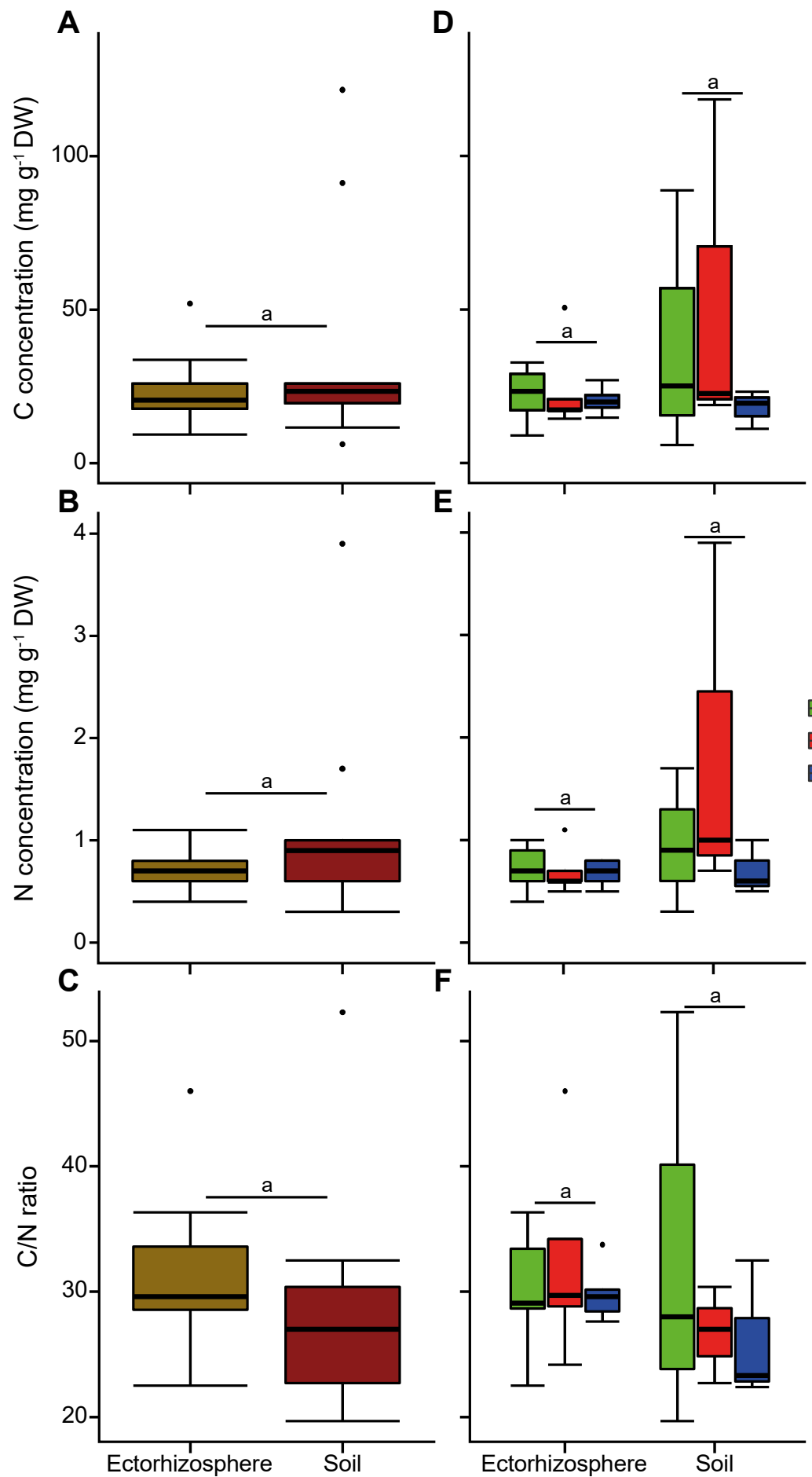

Figure 1. Boxplots of the mass fraction of carbon $(\mathbf{A}, \mathbf{D})$, nitrogen $(\mathbf{B}, \mathbf{E})$ and $\mathrm{C}$ to $\mathrm{N}$ ratio $(\mathbf{C}, \mathbf{F})$ in ectorhizosphere and scarified soil samples. Panels (A-C) depict the nutrient content per sample, and panels (D-F) depict the same data split by fertilization treatment. The lowercase letters in the upper part of the boxplots represent Fisher's least significant difference (LSD) statistical grouping testing sample type effect. Whiskers represent $1.5 \times$ inter-quartile range (IQR). 

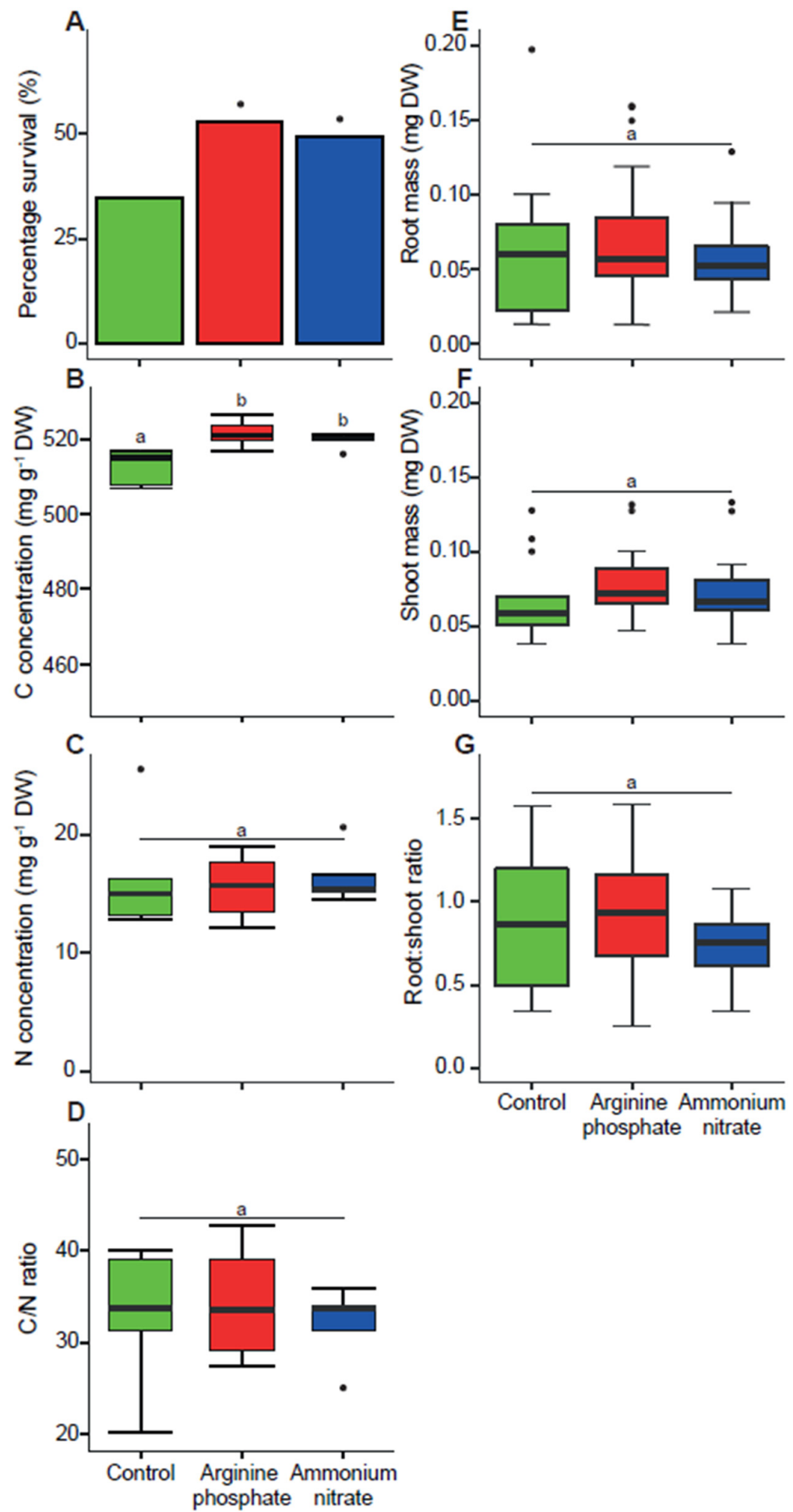

Figure 2. Barplot of the survival rate (A) and boxplots of the mass fraction of needle carbon (B), nitrogen (C), C-to-N ratio (D), root weight (E), shoot weight (F) and root-to-shoot ratio (G) of SeedPAD-planted Scots pine seedlings growing in scarified soil or supplied with either arginine phosphate or ammonium nitrate prior to germination. Asterisks represent statistical differences of Cox proportional hazard regression for $n=100$. Lowercase letters in the upper part of the boxplot represent Fisher's least significant difference (LSD) statistical grouping testing treatment effect. Whiskers represents $1.5 \times$ inter-quartile range (IQR). $n=22$ (arginine phosphate), 18 (ammonium nitrate) and 13 (control). 


\subsection{Early Established Seedlings Are Colonized by Fungi Regardless of Nitrogen Supplementation}

ITS2 amplicon sequence analysis was used to evaluate the fungal communities of the scarified soil, ectorhizosphere and washed roots. In control samples, the scarified and ectorhizosphere soils had, on average, two- and three-times higher richness compared to the roots (Kruskal-Wallis $p$-value $<0.001$; Figure 3A). Diversity indicators showed that both scarified and ectorhizosphere soils had similarly structured fungal communities both in terms of evenness (Kruskal-Wallis p-value $>0.05$; Figure 3B) and diversity (Kruskal-Wallis $p$-value $>0.05$; Figure 3C). Both soil types had more even (Kruskal-Wallis $p$-value $<0.05$ ) and more diverse (Kruskal-Wallis $p$-value $<0.05$ ) communities than the roots, which had a community dominated by fewer ASVs.
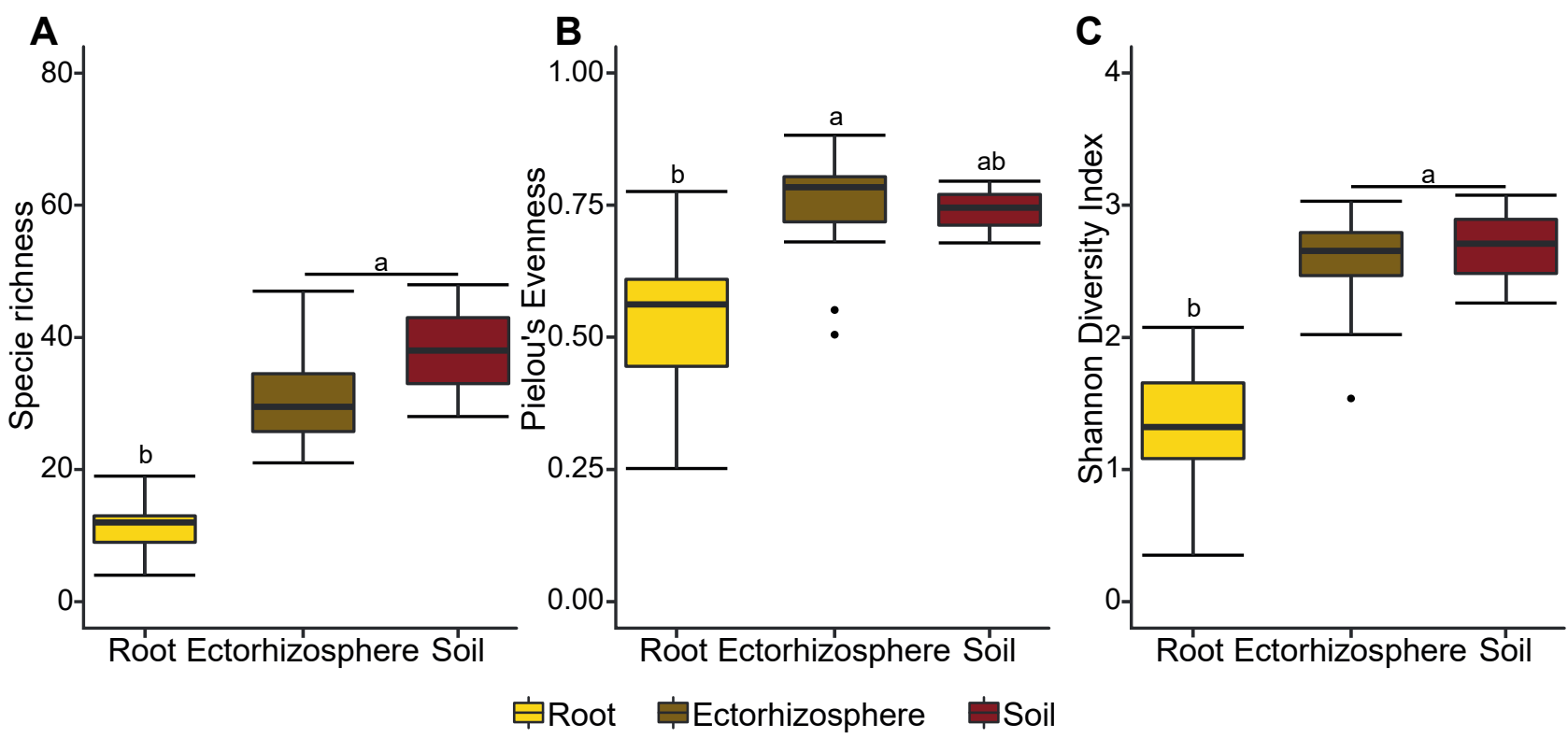

Figure 3. Boxplots of (A) species richness, (B) Pielou's evenness, and (C) Shannon diversity of control samples of roots, ectorhizosphere and scarified soils. Lowercase letters in the upper part of the boxplot represent Fisher's least significant difference (LSD) statistical grouping testing scheme $1.5 \times$ inter-quartile range (IQR).

While species richness, Pielou's evenness and Shannon diversity all provide broad information about community structure, they do not provide information about community composition. An analysis of the community composition indicated that while the scarified soil and ectorhizosphere fungal communities were similar (PERMANOVA; adjusted p-value > 0.05), they harbored different dominant ASVs (Figure 4). For example, within the scarified soil community, the most dominant ASV was identified as belonging to the opportunistic taxon Helotiales sp., while in the ectorhizosphere Leotiomycetes sp., together with ASVs assigned to known saprotrophic taxa such as Penicillium, Umbelopsis, Mortierella and Mycena along with the ericoid mycorrhiza Oidiodendron, were dominant (Figure 4). In contrast, the community composition of the roots was significantly different from both the scarified soil (PERMANOVA adjusted $p$-value $<0.005$ ) and the ectorhizosphere (PERMANOVA adjusted $p$-value $<0.005$ ), with the root-associated fungal community strongly enriched for ectomycorrhizal symbiotrophs such as Russula, Piloderma and Suillus, but depleted in saprotrophic fungi (Figure 4). 


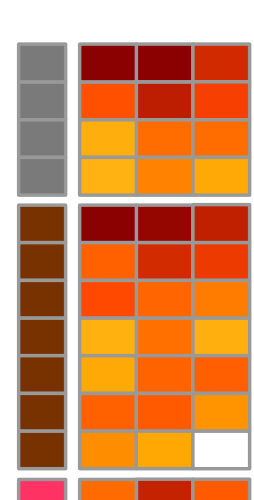

\begin{tabular}{|c|}
\hline Species \\
\hline Ascomycota sp. \\
\hline Fungi sp. \\
\hline GS34 sp. \\
\hline Fungi sp. \\
\hline Helotiales sp. \\
\hline Chaetothyriales sp. \\
\hline Helotiales sp. \\
\hline Chaetothyriales sp. \\
\hline Herpotrichiellaceae sp. \\
\hline Mycena sp. \\
\hline Pleomassariaceae sp. \\
\hline Leotiomycetes sp. \\
\hline
\end{tabular}

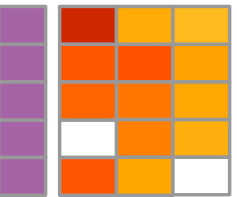

\begin{tabular}{|l|}
\hline Atheliaceae $s p$. \\
\hline Venturiaceae $s p$. \\
\hline Agaricales $s p$. \\
\hline Agaricomycetes $s p$. \\
\hline Cantharellales $s p$. \\
\hline
\end{tabular}

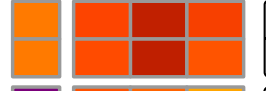

Lecanorales sp.

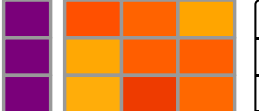

Oidiodendron sp.

\begin{tabular}{|l|}
\hline Auriculariales sp. \\
\hline Umbelopsis sp. \\
\hline
\end{tabular}

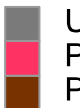

\section{Pathotroph}

Unidentified

Pathotroph-Saprotroph

Pathotroph-Saprotroph-Symbiotroph

Pathotroph-Symbiotroph

Saprotroph

Saprotroph-Symbiotroph

Symbiotroph
Penicillium sp.

Umbelopsis sp.

Solicoccozyma terricola

Botryobasidium $s p$.

Hyaloscyphaceae sp.

Trichoderma sp.

Chaetosphaeriaceae $s p$.

Gyromitra sp.

Archaeorhizomyces sp.

Lycoperdon sp.

Sarcoleotia globosa

Clavaria sp.

Peniophorella praetermissa

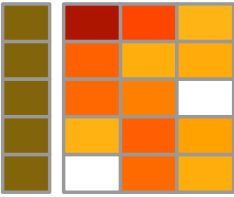

Pyronemataceae $s p$.

Gloniaceae sp.

Sebacinales $s p$.

Mortierella $s p$.

Pleosporales sp.

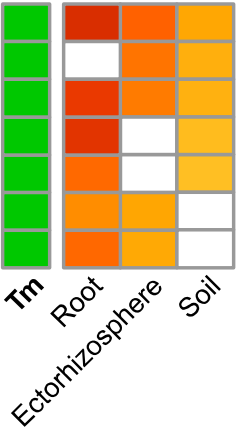

Russula sp.

Cadophora sp.

Piloderma sp.

Suillus sp.

Boletales sp.

Tylospora fibrillosa

Lactarius sp.

Figure 4. Heatmap depicting the most abundant amplicon sequence variants (ASVs) adding up to a total abundance of $50 \%$ of the total community of roots, ectorhizosphere or scarified soils. Left column colored by trophic modes annotated on FUNGuild V1.1. Scale is $\log _{10}$ of the sequencing reads. The complete list of ASVs can be found in Table S3.

When looking closer at the abundances of ECM fungal ASVs in roots, ectorhizosphere and bulk soil, we observed three differing patterns of occurrence (Figures 4 and S4). 
(i) Several ectomycorrhizal ASVs in both types of soil samples, belonging to Russula, Piloderma, Suillus and Cortinariaceae, were enriched in root samples (Symbiotrophs in Figure S4), indicating their presence across the site as well as a rapid colonization of seedling roots. (ii) Two ASVs identified as Cortinarius sp. and Russula densifolia were present in bulk soil samples but never close to or on the seedling roots, which might indicate a preference for other host species or older trees. (iii) Several ectomycorrhizal ASVs (Inocybe soluta, Tomentellopsis echinospora, Tylospora fibrillosa, Amphinema byssoides, Lactarius sp.) were found only on roots and the rhizosphere, potentially indicating that these fungi very specifically grew to colonize the seedlings, with dormant spores in bulk soil staying below the detection threshold (Figures 4 and S4).

PCoA analysis of the N-supplemented samples indicated the presence of a core community that was persistent regardless of $\mathrm{N}$-supplementation treatments. This community included ASVs identified as symbiotrophs, such as Tylospora and Amphinema, as well as ASVs identified as 'pathotroph-symbiotrophs' (e.g., Lecanorales and Oidiodendron) and a large number of unidentified Ascomycota and opportunistic Helotiales and saprotrophs (e.g., Umbelopsis and Penicillium) (Figure S4). Supplementation with arginine phosphate increased the number of unique ASVs in the root-associated community, accounting for $28.5 \%$ of the root-associated community (Figure S5). Despite this increase, no significant differences were found in diversity indexes (Figure S6; Kruskal-Wallis $p$-value > 0.05) nor at compositional level (PERMANOVA adjusted $p$-value $>0.05$ ).

To further test the effect of $\mathrm{N}$ supplementation on the root-associated fungal community recruited by the roots of newly germinated pine seedlings, ectomycorrhiza fungi abundance was estimated based on the ASV counts and statistical significance (Figure 5). From the results, ASVs of the family Pyronemataceae were positively increased by supplementation with either arginine phosphate or ammonium nitrate (Figure 5, Table S4). Another ASV assigned to the genus Russula, which contains both nitrophilic and nitrophobic species [71], showed a significant negative response to $\mathrm{N}$ supplementation (Figure 5; Table S4). An ASV assigned to the mostly N-tolerant genus Lactarius was present only in the arginine phosphate-treated samples (Figure 5). ASVs assigned to the nitrophobic taxon Piloderma showed an increase in abundance in the presence of arginine phosphate, while Suillus showed reduced abundance in response to both $\mathrm{N}$-supplementation treatments (Figure 5). Interestingly, a member of the Cortinariaceae family, which is known to be nitrophobic [71], was only present on roots of fertilized seedlings (Figure S7). 


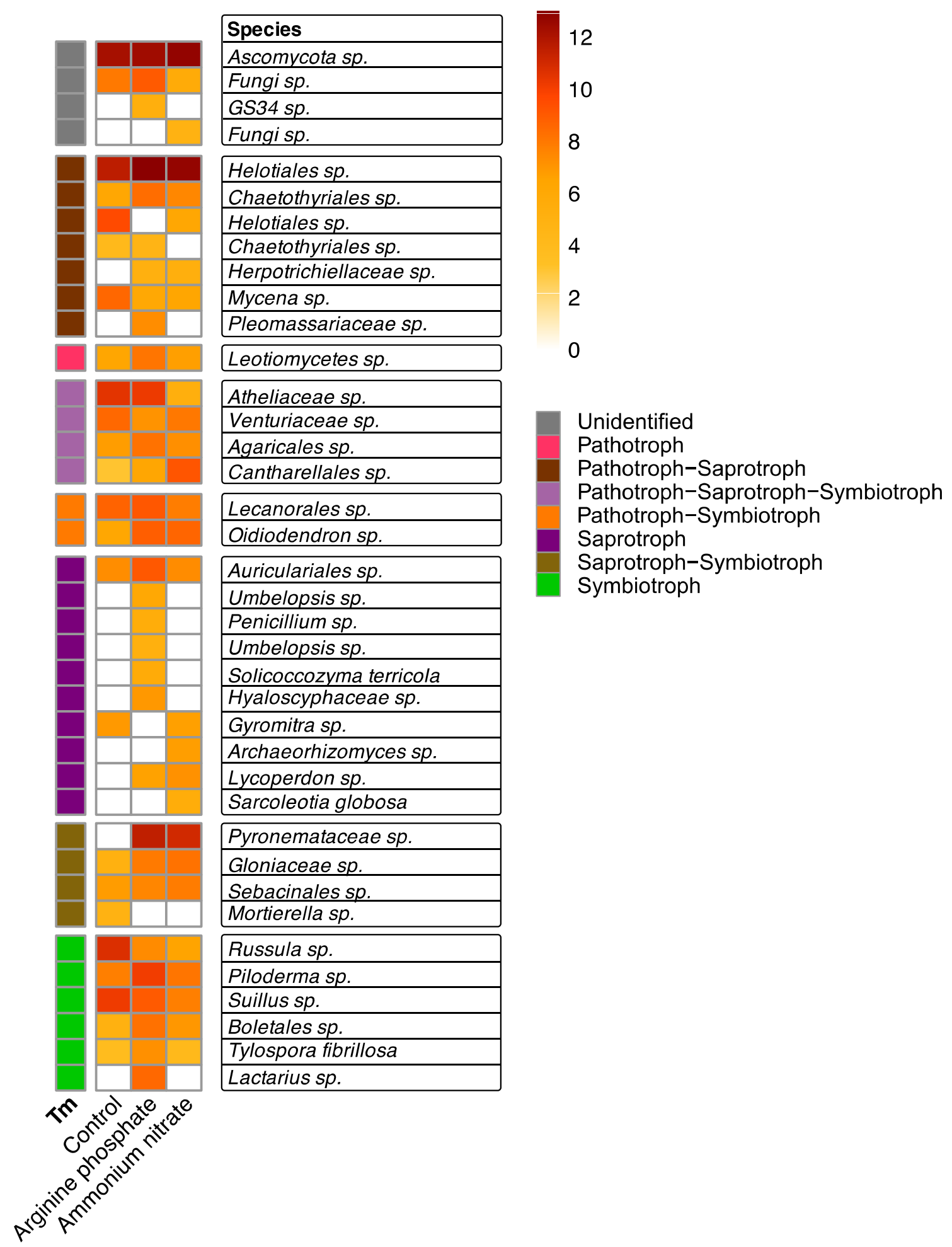

Figure 5. Heatmap depicting the most abundant amplicon sequencing variants (ASVs) with a cumulative presence of $50 \%$ of the total community on roots. Left column colored by trophic modes annotated on FUNGuild V1.1. Scale is $\log _{10}$ of the sequencing reads.

\section{Discussion}

In the Swedish boreal forest, soil scarification is the current practice for site preparation after clear-cut timber harvesting. Clear-cutting stops the transport of current photosynthate to roots and the associated rhizospheric community, which leads to a drastic shift in soil 
fungal communities, reducing ECM abundance [30]. The subsequent soil scarification further disrupts the ECM, leaving only fragments of the previous ECM networks. These scarified clear-cuts are typically replanted with nursery-produced seedlings 2 years after harvesting or, on specific sites, directly sown with orchard-produced seeds. The boreal forest is generally characterized by nutrient-poor soils, with $\mathrm{N}$ being the most limiting nutrient [15], and nursery-produced seedlings are deliberately loaded with nutrients during production to improve initial seedling survival and growth [72-74]. However, it is not known whether the same positive effect of $\mathrm{N}$ supplementation can be achieved upon direct seeding. Our results show that a small addition of either organic or inorganic $\mathrm{N}$ did increase seedling survival ( $p$-value $<0.05)$ and carbon accumulation aboveground $(p$-value $<0.05)$ (Figure 2). Furthermore, we provide evidence for a strong early effect on fungal recruitment by the root, with an enrichment of ECM fungi in the saprobe-dominated, disturbed soil after only a few months (Figure 4).

Reduction in recent plant-sourced $C$ in the soil caused by site preparation (i.e., tree removal and soil scarification) reduces ECM dominance, favoring saprobes [30,75]. Kohout et al. [29] found a progressive shift from an ECM- to saprotrophic-dominated soil community in a spruce forest over a timeframe of around 20 months after harvesting, which corresponds to the time that usually passes between harvest and replanting. Our data are consistent with this finding, showing that saprotrophs were the most dominant trophic mode in the scarified soil and ectorhizosphere (Figure 4; Table S3), accounting for about 15\% of the whole community. However, while greatly diminished, ECM were not completely removed from the scarified soil community of our study site, accounting for about $5 \%$ of the community (Figure S4). The persistence of these ECMs might be explained by hyphae, sclerotia or spores remaining in the soil [76]. These different types of propagules are believed to remain dormant and can be induced to restart growth or germinate, respectively, by the presence of closely growing roots $[76,77]$. Our results clearly show this stimulating effect of the exploring root (Figure 4; Figure S4), with ECMs associated with roots being twice as abundant relative to either the ectorhizosphere or scarified clear-cut soils. Similar results were found by Kyaschenko et al. [78] in a study performed in an age-gradient Scots pine stand, where 1 year after site preparation the soils were saprobe-dominated, while the abundance of ECM was generally low, with a dominance of species such as Piloderma and Tylospora. They proposed that these ECM fungi from the Atheliaceae family are favored by the high levels of soil inorganic $\mathrm{N}$ and host-derived $\mathrm{C}$ in the soils of the younger stand [78]. We also found that Atheliaceae such as Piloderma, Tylospora and Amphinema were among the dominant ECM families in the root samples (about 25\%; Figure S7), supporting the view that they are among the first ECM colonizers of Scots pine seedlings germinating in disturbed soils, and that recruitment by these seedlings occurs very rapidly despite the saprobe-dominated community of the disturbed scarified soil.

Growing in association with already-established ECM is often positive for seedlings, and established ECM fungi can enhance survival at the plant community level [79]. However, it has been observed that under some environments, such as nutrient-poor soils, belowground interactions limit seedling growth due to their low competitive strength against adult trees $[14,25,80,81]$. Thus, although seedlings that germinate in undisturbed boreal forest soils have access to established mycorrhiza, from which they may gain valuable nutrients [82], seedling establishment in such undisturbed forests is often poor, and these seedlings are generally smaller compared to those that establish in scarified soils [25]. This was illustrated by Axelsson et al., [25] who performed an experiment in a Scots pine stand where they observed that the seedlings successfully established and grew larger, both when $C$ flux belowground was eliminated by girdling the adult trees, or in a clear-cut ca. $10 \mathrm{~m}$ away from the forest edge [25]. Similar results were found by Pasanen et al., [26] in artificial canopy gaps with soil preparation in a Scots pine-dominated forest, where most of the establishing seedlings were found in the disturbed soil plots [26]. Thus, in highly disturbed soils, such as a scarified clear-cut site, where mycorrhizal networks and plantderived $\mathrm{C}$ flux have been heavily disrupted, initial seedling establishment is enhanced and 
resistant propagules (i.e., sclerotia and spores) become the dominant mycorrhizal inoculum source $[76,83,84]$. This might explain why we found some ECM fungi such as Inocybe soluta, Tomentellopsis echinospora or Amphinema byssoides at relatively high abundances in root and rhizosphere samples, while being absent from bulk soil samples (Figure S4). Their apparent absence in the bulk soil might be due to these propagules falling below the detection threshold of our profiling method, while other ectomycorrhizal ASVs belonging to Russula and Piloderma were still present in the disturbed soil with relatively higher biomass abundance, possibly due to higher resilience to disturbance or higher abundances before clear-cutting.

The addition of a small amount of $\mathrm{N}$ to the germinating seedling did not significantly alter the already-strong selective pressure of the roots on the fungal community (Table S4). However, we did find evidence of initial changes in the abundance of specific fungal ASVs, particularly in Pyronemataceae sp. and Russula (adjusted $p$-value $<0.01 ; \log 2$ Fold $>2$ ). Although the specific nature of most Pyronemataceae is unknown, different members of the family have been characterized as saprobes or ectomycorrhizal [85,86], while Russula is a large ECM genus with both nitrophobic and nitrophilic species, and is typically dominant in older stands $[71,78,87]$. Within the other ASVs recruited by the roots, the nitrophobic Suillus was negatively affected by both arginine phosphate and ammonium nitrate (Figure 5) while Piloderma, which has the ability to take up, use and deliver amino acids to Scots pine [88], responded positively to the addition of arginine phosphate but not ammonium nitrate (Figure 5). While previous large-scale studies have shown that short-term $\mathrm{N}$ addition to undisturbed boreal forest soils had no significant influence on root-associated fungal communities [54,89], our study showed that small, localized applications of either organic or inorganic $\mathrm{N}$ in disturbed soils both increases seedling survival and facilitates the rapid recruitment of some taxa of ECM fungi, such as members of Pyronemataceae, Cortinariaceae and Piloderma.

\section{Conclusions}

Traditional forest management includes clear-cutting of mature trees and subsequent soil scarification for new seedling plantations. While this increases seedling establishment success and growth, its collateral effect is the local disruption of the soil, altering nutrient equilibrium and microbial composition. Further complicating future management decisions, the impacts of climate change-related increases in air and soil temperatures and increasing drought on the plant-soil community interaction are uncertain. While increases in soil temperature are expected to enhance seed germination and survival in the northern hemisphere [90-92], higher soil temperatures are also known to reduce ECM formation [39,40], potentially leaving the roots more vulnerable to pathogen attacks [93] or drought. Our study provides evidence that small-scale $\mathrm{N}$ addition to onsite-planted seeds can be used to enhance seedling establishment without $\mathrm{N}$ leakage into the soil, and that such small-scale $\mathrm{N}$ addition does not significantly alter the strong selective pressure of the growing root in rapidly reshaping the root-associated fungal community from the opportunistic dominated community of the scarified soil into an ECM-dominated community.

Supplementary Materials: The following are available online at https: / www.mdpi.com/article / 10.3390/f12111589/s1, Figure S1: SeedPAD ${ }^{\mathrm{TM}}$ germination matrix, Figure S2: Site description, Figure S3: Site temperature and precipitation data, Figure S4: Whole fungal community for roots, ectorhizosphere and soil samples, Figure S5: Venn diagram of root ASVs by treatment, Figure S6: Violin plot of richness, Pielou's evenness and Shannon diversity of root samples by treatment, Figure S7: Whole root fungal community by treatment, Table S1: ITS2 Primer sequence, Table S2: Barcode combination used by sample, Table S3: Whole community taxonomy, Table S4: Differentially abundant taxa results.

Author Contributions: Conceptualization, V.H., N.R.S. and T.N.; methodology, V.H., N.R.S., T.N. and M.H.; software, D.C.; validation, D.C. and A.N.S.; formal analysis, D.C.; investigation, D.C. and A.N.S.; resources, D.C. and A.N.S.; data curation, D.C.; writing-original draft preparation, D.C. and A.N.S.; writing-review and editing, D.C., A.N.S., V.H., N.R.S. and T.N.; visualization, D.C.; 
supervision, V.H.; project administration, V.H., N.R.S., T.N. and M.H.; funding acquisition, V.H., N.R.S. and T.N. All authors have read and agreed to the published version of the manuscript.

Funding: This research was supported by funds from the Swedish University of Agricultural Science's Trees and Crops for the Future (TC4F) program to V.H., T.N. and N.R.S., D.C. PhD studies were funded by Becas Chile Scholarship (CONICYT 2015; number 72160239).

Data Availability Statement: The dataset generated and analyzed in this study is available in the European Nucleotide Archive (ENA; https:/ / www.ebi.ac.uk/ena/browser/home, accessed on 17 November 2021) and is available under the accession number PRJEB48062.

Acknowledgments: The authors acknowledge support from the National Genomics Infrastructure in Genomics Production Stockholm funded by Science for Life Laboratory, the Knut and Alice Wallenberg Foundation and the Swedish Research Council. The computations were enabled by resources provided by the Swedish National Infrastructure for Computing (SNIC) at UPPMAX partially funded by the Swedish Research Council through grant agreement no. 2018-05973 and by the Umeå Plant Science Centre bioinformatics facility (UPSCb). The authors acknowledge Arevo for providing seedPAD and fertilizers and HolmenSkog AB for providing Scots pine seeds; and Jenny Ekman and Jonas Lundholm from Stable Isotope Laboratory (SSIL) and The Biogeochemical Analyses Laboratory (BAL) of the Swedish University of Agricultural Science for the analyses of soil and needle $\mathrm{C}$ and $\mathrm{N}$ content.

Conflicts of Interest: The authors declare no conflict of interest.

\section{References}

1. Näsholm, T.; Ekblad, A.; Nordin, A.; Giesler, R.; Högberg, M.; Högberg, P. Boreal forest plants take up organic nitrogen. Nature 1998, 392, 914-916. [CrossRef]

2. Nilsson, M.C.; Wardle, D.A. Understory vegetation as a forest ecosystem driver: Evidence from the northern Swedish boreal forest. Front. Ecol. Environ. 2005, 3, 421-428. [CrossRef]

3. Soja, A.J.; Tchebakova, N.M.; French, N.H.F.; Flannigan, M.D.; Shugart, H.H.; Stocks, B.J.; Sukhinin, A.I.; Parfenova, E.I.; Chapin, F.S.; Stackhouse, P.W. Climate-induced boreal forest change: Predictions versus current observations. Glob. Planet. Chang. 2007, 56, 274-296. [CrossRef]

4. $\quad$ Post, W.M.; Emanuel, W.R.; Zinke, P.J.; Stangenberger, A.G. Soil carbon pools and world life zones. Nature 1982, 298, 156-159. [CrossRef]

5. Tamm, C.O. Nitrogen in Terrestrial Ecosystems; Ecological Studies; Springer: Berlin/Heidelberg, Germany, 1991; Volume 81, ISBN 978-3-642-75170-7.

6. Taylor, A.F.S.; Martin, F.; Read, D.J. Fungal Diversity in Ectomycorrhizal Communities of Norway Spruce [Picea abies (L.) Karst.] and Beech (Fagus sylvatica L.) Along North-South Transects in Europe. In Carbon and Nitrogen Cycling in European Forest Ecosystems; Springer: Berlin/Heidelberg, Germany, 2000; pp. 343-365.

7. Tedersoo, L.; Bahram, M.; Põlme, S.; Kõljalg, U.; Yorou, N.S.; Wijesundera, R.; Villarreal Ruiz, L.; Vasco-Palacios, A.M.; Thu, P.Q.; Suija, A.; et al. Fungal biogeography. Global diversity and geography of soil fungi. Science 2014, 346, 1256688. [CrossRef]

8. Menkis, A.; Vasiliauskas, R.; Taylor, A.F.S.; Stenlid, J.; Finlay, R. Fungal communities in mycorrhizal roots of conifer seedlings in forest nurseries under different cultivation systems, assessed by morphotyping, direct sequencing and mycelial isolation. Mycorrhiza 2005, 16, 33-41. [CrossRef]

9. Alberton, O.; Kuyper, T.W.; Gorissen, A. Competition for nitrogen between Pinus sylvestris and ectomycorrhizal fungi generates potential for negative feedback under elevated $\mathrm{CO}_{2}$. Plant Soil 2007, 296, 159-172. [CrossRef]

10. Johnson, N.C.; Graham, J.H.; Smith, F.A. Functioning of mycorrhizal associations along the mutualism-parasitism continuum. New Phytol. 1997, 135, 575-585. [CrossRef]

11. Ågren, G.I.; Hyvönen, R.; Baskaran, P. Ectomycorrhiza, Friend or Foe? Ecosystems 2019, 22, 1561-1572. [CrossRef]

12. Näsholm, T.; Högberg, P.; Franklin, O.; Metcalfe, D.; Keel, S.G.; Campbell, C.; Hurry, V.; Linder, S.; Högberg, M.N. Are ectomycorrhizal fungi alleviating or aggravating nitrogen limitation of tree growth in boreal forests? New Phytol. 2013, 198, 214-221. [CrossRef]

13. Maher Hasselquist, E.; Hasselquist, N.J.; Sparks, J.P.; Nilsson, C. Recovery of nitrogen cycling in riparian zones after stream restoration using $\delta 15 \mathrm{~N}$ along a 25-year chronosequence in northern Sweden. Plant Soil 2017, 410, 423-436. [CrossRef]

14. Henriksson, N.; Franklin, O.; Tarvainen, L.; Marshall, J.; Lundberg-Felten, J.; Eilertsen, L.; Näsholm, T. The mycorrhizal tragedy of the commons. Ecol. Lett. 2021, 24, 1215-1224. [CrossRef] [PubMed]

15. Juday, G.P. Forests, Land Management, and Agriculture. In Arctic Climate Impact Assessment; Cambridge University Press: Cambridge, UK, 2005; pp. 781-862. ISBN 0-521-86509-3.

16. Mason, W.L.; Alía, R. Current and future status of Scots Pine (Pinus sylvestnis L.) forests in Europe. For. Syst. $2000,9,317-335$.

17. Zackisson, O. Influence of Forest Fires on the North Swedish boreal forest. Oikos 1977, 29, 22-32. [CrossRef] 
18. Santoro, M.; Pantze, A.; Fransson, J.E.S.; Dahlgren, J.; Persson, A. Nation-Wide Clear-Cut Mapping in Sweden Using ALOS PALSAR Strip Images. Remote Sens. 2012, 4, 1693-1715. [CrossRef]

19. Wallin, I. Forest Management and Governance in Sweden A Phronetic Analysis of Social Practices. Ph.D. Thesis, Swedish University of Agricultural Sciences, Uppsala, Sweden, 2017.

20. Ceccon, E.; González, E.J.; Martorell, C. Is Direct Seeding a Biologically Viable Strategy for Restoring Forest Ecosystems? Evidences from a Meta-analysis. L. Degrad. Dev. 2016, 27, 511-520. [CrossRef]

21. Wennström, U. Direct Seeding of Pinus sylvestvis (L.) in the Boreal Forest Using Orchard or Stand Seed. Ph.D. Thesis, Swedish University of Agricultural Sciences, Uppsala, Sweden, 2001.

22. Mäkitalo, K. Effect of Site Preparation and Reforestation Method on Survival and Height Growth of Scots Pine. Scand. J. For. Res. 1999, 14, 512-525. [CrossRef]

23. Karlsson, M.; Nilsson, U.; Örlander, G. Natural Regeneration in Clear-cuts: Effects of Scarification, Slash Removal and Clear-cut Age. Scand. J. For. Res. 2002, 17, 131-138. [CrossRef]

24. Piirainen, S.; Finér, L.; Mannerkoski, H.; Starr, M. Carbon, nitrogen and phosphorus leaching after site preparation at a boreal forest clear-cut area. For. Ecol. Manag. 2007, 243, 10-18. [CrossRef]

25. Axelsson, E.; Lundmark, T.; Högberg, P.; Nordin, A. Belowground Competition Directs Spatial Patterns of Seedling Growth in Boreal Pine Forests in Fennoscandia. Forests 2014, 5, 2106-2121. [CrossRef]

26. Pasanen, H.; Rouvinen, S.; Kouki, J. Artificial canopy gaps in the restoration of boreal conservation areas: Long-term effects on tree seedling establishment in pine-dominated forests. Eur. J. For. Res. 2016, 135, 697-706. [CrossRef]

27. Keenan, R.J.; Kimmins, J.P. The ecological effects of clear-cutting. Environ.Rev. 1993, 1, 121-144. [CrossRef]

28. Pennock, D.J.; van Kessel, C. Clear-cut forest harvest impacts on soil quality indicators in the mixedwood forest of Saskatchewan, Canada. Geoderma 1997, 75, 13-32. [CrossRef]

29. Kohout, P.; Charvátová, M.; Štursová, M.; Mašínová, T.; Tomšovský, M.; Baldrian, P. Clearcutting alters decomposition processes and initiates complex restructuring of fungal communities in soil and tree roots. ISME J. 2018, 12, 692-703. [CrossRef]

30. Lindahl, B.D.; de Boer, W.; Finlay, R.D. Disruption of root carbon transport into forest humus stimulates fungal opportunists at the expense of mycorrhizal fungi. ISME J. 2010, 4, 872-881. [CrossRef] [PubMed]

31. Kataja-aho, S.; Fritze, H.; Haimi, J. Short-term responses of soil decomposer and plant communities to stump harvesting in boreal forests. For. Ecol. Manag. 2011, 262, 379-388. [CrossRef]

32. Jiménez Esquilín, A.E.; Stromberger, M.E.; Shepperd, W.D. Soil Scarification and Wildfire Interactions and Effects on Microbial Communities and Carbon. Soil Sci. Soc. Am. J. 2008, 72, 111-118. [CrossRef]

33. Leake, J.; Johnson, D.; Donnelly, D.; Muckle, G.; Boddy, L.; Read, D. Networks of power and influence: The role of mycorrhizal mycelium in controlling plant communities and agroecosystem functioning. Can. J. Bot. 2004, 82, 1016-1045. [CrossRef]

34. Bååth, E.; Frostegård, Å.; Pennanen, T.; Fritze, H. Microbial community structure and pH response in relation to soil organic matter quality in wood-ash fertilized, clear-cut or burned coniferous forest soils. Soil Biol. Biochem. 1995, 27, 229-240. [CrossRef]

35. Houston, A.P.C.; Visser, S.; Lautenschlager, R.A. Microbial processes and fungal community structure in soils from clear-cut and unharvested areas of two mixedwood forests. Can. J. Bot. 1998, 76, 630-640.

36. Moore-Kucera, J.; Dick, R.P. PLFA Profiling of Microbial Community Structure and Seasonal Shifts in Soils of a Douglas-fir Chronosequence. Microb. Ecol. 2008, 55, 500-511. [CrossRef] [PubMed]

37. Pennanen, T.; Liski, J.; Bååth, E.; Kitunen, V.; Uotila, J.; Westman, C.J.; Fritze, H. Structure of the Microbial Communities in Coniferous Forest Soils in Relation to Site Fertility and Stand Development Stage. Microb. Ecol. 1999, 38, 168-179. [CrossRef] [PubMed]

38. Settele, J.; Scholes, R.; Betts, R.A.; Bunn, S.; Leadley, P.; Nepstad, D.; Overpeck, J.T.; Taboada, M.A. Terrestrial and Inland Water Systems. In Climate Change 2014: Impacts, Adaptation, and Vulnerability.Part A: Global and Sectoral Aspects. Contribution of Working Group II to the Fifth Assessment Report of theIntergovernmental Panel on Climate Change; Field, C.B., Barros, V.R., Dokken, D.J., Mach, K.J., Mastrandrea, M.D., Bilir, T.E., Chatterjee, M., Ebi, K.L., Estrada, Y.O., Genova, R.C., et al., Eds.; Cambridge University Press: New York, NY, USA, 2014; pp. 271-359.

39. Kilpeläinen, J.; Barbero-López, A.; Vestberg, M.; Heiskanen, J.; Lehto, T. Does severe soil drought have after-effects on arbuscular and ectomycorrhizal root colonisation and plant nutrition? Plant Soil 2017, 418, 377-386. [CrossRef]

40. Kilpeläinen, J.; Aphalo, P.J.; Lehto, T. Temperature affected the formation of arbuscular mycorrhizas and ectomycorrhizas in Populus angustifolia seedlings more than a mild drought. Soil Biol. Biochem. 2020, 146, 107798. [CrossRef]

41. Li, Y.; Zhang, T.; Zhou, Y.; Zou, X.; Yin, Y.; Li, H.; Liu, L.; Zhang, S. Ectomycorrhizal symbioses increase soil calcium availability and water use efficiency of Quercus acutissima seedlings under drought stress. Eur. J. For. Res. 2021, 140, 1039-1048. [CrossRef]

42. Li, M.; Wang, H.; Zhao, X.; Lu, Z.; Sun, X.; Ding, G. Role of Suillus placidus in Improving the Drought Tolerance of Masson Pine (Pinus massoniana Lamb.) Seedlings. Forests 2021, 12, 332. [CrossRef]

43. Lindkvist, A.; Kardell, Ö.; Nordlund, C. Intensive forestry as progress or decay? An analysis of the debate about forest fertilization in Sweden, 1960-2010. Forests 2011, 2, 112-146. [CrossRef]

44. Pukkala, T. Optimal nitrogen fertilization of boreal conifer forest. For. Ecosyst. 2017, 4, 3. [CrossRef]

45. Simonsen, R.; Rosvall, O.; Gong, P.; Wibe, S. Profitability of measures to increase forest growth. For. Policy Econ. 2010, 12, 473-482. [CrossRef] 
46. Gruffman, L.; Ishida, T.; Nordin, A.; Näsholm, T. Cultivation of Norway spruce and Scots pine on organic nitrogen improves seedling morphology and field performance. For. Ecol. Manag. 2012, 276, 118-124. [CrossRef]

47. Davis, A.S.; Jacobs, D.F. Quantifying root system quality of nursery seedlings and relationship to outplanting performance. New For. 2005, 30, 295-311. [CrossRef]

48. Vaario, L.-M.; Tervonen, A.; Haukioja, K.; Haukioja, M.; Pennanen, T.; Timonen, S. The effect of nursery substrate and fertilization on the growth and ectomycorrhizal status of containerized and outplanted seedlings of Picea abies. Can. J. For. Res. 2009, 39, 64-75. [CrossRef]

49. Werner, R.A.; Bruch, B.A.; Brand, W.A. ConFlo III-An interface for high precision $\delta 13 \mathrm{C}$ and $\delta 15 \mathrm{~N}$ analysis with an extended dynamic range. Rapid Commun. Mass Spectrom. 1999, 13, 1237-1241. [CrossRef]

50. Hanania, U.; Velcheva, M.; Sahar, N.; Perl, A. An improved method for isolating high-quality DNA fromVitis vinifera nuclei. Plant Mol. Biol. Report 2004, 22, 173-177. [CrossRef]

51. Beckers, B.; Op De Beeck, M.; Thijs, S.; Truyens, S.; Weyens, N.; Boerjan, W.; Vangronsveld, J. Performance of 16s rDNA Primer Pairs in the Study of Rhizosphere and Endosphere Bacterial Microbiomes in Metabarcoding Studies. Front. Microbiol. 2016, 7, 650. [CrossRef] [PubMed]

52. White, T.J.; Bruns, T.; Lee, S.; Taylor, J. Amplification and direct sequencing of fungal ribosomal rna genes for phylogenetics. In PCR Protocols; Academic Press: Cambridge, MA, USA, 1990; pp. 315-322.

53. Ihrmark, K.; Bödeker, I.T.M.; Cruz-Martinez, K.; Friberg, H.; Kubartova, A.; Schenck, J.; Strid, Y.; Stenlid, J.; Brandström-Durling, M.; Clemmensen, K.E.; et al. New primers to amplify the fungal ITS2 region-evaluation by 454 -sequencing of artificial and natural communities. FEMS Microbiol. Ecol. 2012, 82, 666-677. [CrossRef]

54. Haas, J.C.; Street, N.R.; Sjödin, A.; Lee, N.M.; Högberg, M.N.; Näsholm, T.; Hurry, V. Microbial community response to growing season and plant nutrient optimisation in a boreal Norway spruce forest. Soil Biol. Biochem. 2018, 125, 197-209. [CrossRef]

55. Bolyen, E.; Rideout, J.R.; Dillon, M.R.; Bokulich, N.A.; Abnet, C.C.; Al-Ghalith, G.A.; Alexander, H.; Alm, E.J.; Arumugam, M.; Asnicar, F.; et al. Reproducible, interactive, scalable and extensible microbiome data science using QIIME 2. Nat. Biotechnol. 2019, 37, 852-857. [CrossRef]

56. Callahan, B.J.; McMurdie, P.J.; Rosen, M.J.; Han, A.W.; Johnson, A.J.A.; Holmes, S.P. DADA2: High-resolution sample inference from Illumina amplicon data. Nat. Methods 2016, 13, 581-583. [CrossRef]

57. Bokulich, N.A.; Kaehler, B.D.; Rideout, J.R.; Dillon, M.; Bolyen, E.; Knight, R.; Huttley, G.A.; Gregory Caporaso, J. Optimizing taxonomic classification of marker-gene amplicon sequences with QIIME 2's q2-feature-classifier plugin. Microbiome 2018, 6, e3208v2. [CrossRef] [PubMed]

58. Kõljalg, U.; Larsson, K.-H.; Abarenkov, K.; Nilsson, R.H.; Alexander, I.J.; Eberhardt, U.; Erland, S.; Høiland, K.; Kjøller, R.; Larsson, E.; et al. UNITE: A database providing web-based methods for the molecular identification of ectomycorrhizal fungi. New Phytol. 2005, 166, 1063-1068. [CrossRef] [PubMed]

59. Katoh, K. MAFFT: A novel method for rapid multiple sequence alignment based on fast Fourier transform. Nucleic Acids Res. 2002, 30, 3059-3066. [CrossRef]

60. Price, M.N.; Dehal, P.S.; Arkin, A.P. FastTree 2-Approximately Maximum-Likelihood Trees for Large Alignments. PLoS ONE 2010, 5, e9490. [CrossRef] [PubMed]

61. Nguyen, N.H.; Song, Z.; Bates, S.T.; Branco, S.; Tedersoo, L.; Menke, J.; Schilling, J.S.; Kennedy, P.G. FUNGuild: An open annotation tool for parsing fungal community datasets by ecological guild. Fungal Ecol. 2016, 20, 241-248. [CrossRef]

62. De Mendiburu, F. Agricolae: Statistical Procedures for Agricultural Research. R Package Version 1.3-5. 2020. Available online: https: / /CRAN.R-project.org/package=survival (accessed on 27 September 2021).

63. Therneau, T.M. A Package for Survival Analysis in R. R Package Version 3.2-13. 2020. Available online: https: / /CRAN.R-project. org / package=agricolae (accessed on 27 September 2021).

64. Therneau, T.M.; Grambsch, P.M. Modeling Survival Data: Extending the \{C\}ox Model; Springer: New York, NY, USA, 2000; ISBN 0-387-98784-3.

65. R Core Team. R: A Language and Environment for Statistical Computing; R Foundation for Statistical Computing: Vienna, Austria, 2019.

66. McMurdie, P.J.; Holmes, S. phyloseq: An R package for reproducible interactive analysis and graphics of microbiome census data. PLOS ONE 2013, 8, e61217.

67. Gentleman, R.; Carey, V.; Huber, W.; Hahne, F. Genefilter: Methods for Filtering Genes from High-Throughput Experiments 2018. Available online: http://web.mit.edu/ \{\}r/current/arch/i386_linux26/lib/R/library/genefilter/html/00Index.html (accessed on 27 September 2021).

68. Kembel, S.W.; Cowan, P.D.; Helmus, M.R.; Cornwell, W.K.; Morlon, H.; Ackerly, D.D.; Blomberg, S.P.; Webb, C.O. Picante: $\{$ R\} tools for integrating phylogenies and ecology. Bioinformatics 2010, 26, 1463-1464. [CrossRef]

69. Oksanen, J.; Blanchet, F.G.; Friendly, M.; Kindt, R.; Legendre, P.; McGlinn, D.; Minchin, P.R.; O’Hara, R.B.; Simpson, G.L.; Solymos, P.; et al. Vegan: Community Ecology Package 2019. Available online: https:/ / cran.r-project.org/web/packages/vegan/index. html (accessed on 27 September 2021).

70. Love, M.I.; Huber, W.; Anders, S. Moderated estimation of fold change and dispersion for RNA-seq data with DESeq2. Genome Biol. 2014, 15, 550. [CrossRef] 
71. Lilleskov, E.A.; Hobbie, E.A.; Horton, T.R. Conservation of ectomycorrhizal fungi: Exploring the linkages between functional and taxonomic responses to anthropogenic N deposition. Fungal Ecol. 2011, 4, 174-183. [CrossRef]

72. Jonsdottir, R.J.; Sigurdsson, B.D.; Lindström, A. Effects of nutrient loading and fertilization at planting on growth and nutrient status of Lutz spruce (Picea x lutzii) seedlings during the first growing season in Iceland. Scand. J. For. Res. 2013, $28,631-641$. [CrossRef]

73. Heiskanen, J.; Lahti, M.; Luoranen, J.; Rikala, R. Nutrient loading has a transitory effect on the nitrogen status and growth of outplanted norway spruce seedlings. Silva Fenn. 2009, 43, 249-260. [CrossRef]

74. Luoranen, J.; Rikala, R. Nutrient loading of Norway spruce seedlings hastens bud burst and enhances root growth after outplanting. Silva Fenn. 2011, 45, 319-329. [CrossRef]

75. Fernandez, C.W.; Kennedy, P.G. Revisiting the 'Gadgil effect': Do interguild fungal interactions control carbon cycling in forest soils? New Phytol. 2016, 209, 1382-1394. [CrossRef] [PubMed]

76. Jones, M.D.; Durall, D.M.; Cairney, J.W.G.G. Ectomycorrhizal fungal communities in young forest stands regenerating after clearcut logging. New Phytol. 2003, 157, 399-422. [CrossRef]

77. Ishida, T.A.; Nara, K.; Tanaka, M.; Kinoshita, A.; Hogetsu, T. Germination and infectivity of ectomycorrhizal fungal spores in relation to their ecological traits during primary succession. New Phytol. 2008, 180, 491-500. [CrossRef] [PubMed]

78. Kyaschenko, J.; Clemmensen, K.E.; Hagenbo, A.; Karltun, E.; Lindahl, B.D. Shift in fungal communities and associated enzyme activities along an age gradient of managed Pinus sylvestris stands. ISME J. 2017, 11, 863-874. [CrossRef] [PubMed]

79. Whitfield, J. Underground networking. Nature 2007, 449, 136-138. [CrossRef]

80. Coomes, D.; Grubb, P.J. Impacts of root competition in forests and woodlands: A theoretical framework and review of experiments. Ecol. Monogr. 2000, 70, 171-207. [CrossRef]

81. Högberg, P.; Näsholm, T.; Franklin, O.; Högberg, M.N. Tamm Review: On the nature of the nitrogen limitation to plant growth in Fennoscandian boreal forests. For. Ecol. Manag. 2017, 403, 161-185. [CrossRef]

82. Horton, T.R.; van der Heijden, M.G.A. The role of symbioses in seedling establishment and survival. In Seedling Ecology and Evolution; Leck, M.A., Parker, V.T., Simpson, R.L., Eds.; Cambridge University Press: Cambridge, UK, 2008; pp. 189-214. ISBN 9780511815133.

83. Baar, J.; Horton, T.R.; Kretzer, A.; Bruns, T.D. From Resistant Propagules After a Stand- Replacing Wildfire. New Phytol. 1999, 143, 409-418. [CrossRef]

84. Glassman, S.I.; Levine, C.R.; Dirocco, A.M.; Battles, J.J.; Bruns, T.D. Ectomycorrhizal fungal spore bank recovery after a severe forest fire: Some like it hot. ISME J. 2016, 10, 1228-1239. [CrossRef]

85. Perry, B.A.; Hansen, K.; Pfister, D.H. A phylogenetic overview of the family Pyronemataceae (Ascomycota, Pezizales). Mycol. Res. 2007, 111, 549-571. [CrossRef]

86. Tedersoo, L.; Hansen, K.; Perry, B.A.; Kjøller, R. Molecular and morphological diversity of pezizalean ectomycorrhiza. New Phytol. 2006, 170, 581-596. [CrossRef]

87. Davey, M.L.; Skogen, M.J.; Heegaard, E.; Halvorsen, R.; Kauserud, H.; Ohlson, M. Host and tissue variations overshadow the response of boreal moss-associated fungal communities to increased nitrogen load. Mol. Ecol. 2017, 26, 571-588. [CrossRef] [PubMed]

88. Heinonsalo, J.; Sun, H.; Santalahti, M.; Bäcklund, K.; Hari, P.; Pumpanen, J. Evidences on the ability of mycorrhizal genus Piloderma to use organic nitrogen and deliver it to Scots pine. PLoS ONE 2015, 10, e0131561. [CrossRef]

89. Ishida, T.A.; Nordin, A. No evidence that nitrogen enrichment affect fungal communities of Vaccinium roots in two contrasting boreal forest types. Soil Biol. Biochem. 2010, 42, 234-243. [CrossRef]

90. Reich, P.B.; Oleksyn, J. Climate warming will reduce growth and survival of Scots pine except in the far north. Ecol. Lett. 2008, 11, 588-597. [CrossRef] [PubMed]

91. Gareca, E.E.; Vandelook, F.; Fernández, M.; Hermy, M.; Honnay, O. Seed germination, hydrothermal time models and the effects of global warming on a threatened high Andean tree species. Seed Sci. Res. 2012, 22, 287-298. [CrossRef]

92. Matías, L.; Jump, A.S. Impacts of predicted climate change on recruitment at the geographical limits of Scots pine. J. Exp. Bot. 2014, 65, 299-310. [CrossRef]

93. Sturrock, R.N.; Frankel, S.J.; Brown, A.V.; Hennon, P.E.; Kliejunas, J.T.; Lewis, K.J.; Worrall, J.J.; Woods, A.J. Climate change and forest diseases. Plant Pathol. 2011, 60, 133-149. [CrossRef] 